\title{
INDIGENOUS EXPERIENCE AS A STRATEGY TO DEVELOP RURAL TOURISM IDENTITY
}

\author{
PENGALAMAN PRIBUMI SEBAGAI STRATEGI \\ MENGEMBANGKAN IDENTITAS DESA WISATA
${ }^{* 1}$ Heni Indrayani, ${ }^{2}$ Candra Yudha Satriya, ${ }^{3}$ Astini Kumalasari, ${ }^{4}$ Puji Lestari, ${ }^{5}$ Pandu Cahyoning Negoro, ${ }^{6}$ Jazzirotul Ma'na 1,2,3,4,5,6Universitas Dian Nuswantoro, Semarang \\ Submitted: 17-05-2021; Revised: 03-08-2021; Accepted: 05-08-2021
}

\begin{abstract}
Rural tourism is often seen as a tourist attraction, where tourists make their visit only to catch a glimpse of the village's potential. In contrast to this trend, the rural tourism of in Tanon sub village of in the Semarang regency (Central Java) attempts to offer more by developing its local strength as "Desa Menari" (lit. Dancing Village). It offers tour packages that invite tourists to experience a life in the village, interact with local communities, find happiness, and reinterpret life. The objective of this study is to find out how the local community uses indigenous experience as a strategy to develop rural tourism in the area. This study implemented the communication theory of identity (CTI) by applying qualitative method with a case study approach. After observation and in-depth interview were conducted to rural tourism community, this study found that rural tourism community actively introduces tourism based on local wisdom experiences through the conservation of tourism in Dusun Tanon, including the conservations of community arts, traditional games, and farmer. Indigenous experience as a village identity is constructed according to its purpose, i.e. spreading harmony, knitting inspiration, and reaping memory. This village identity includes personal identity, relational identity, and enacted identity that invite tourists to capture the process of self-meaning or journey into oneself as a psychological experience.
\end{abstract}

Keywords: communication theory of identity (CTI); Desa Menari; indigenous experience; self meaning; rural tourism.

\begin{abstract}
ABSTRAK
Wisata desa sering dilihat sebagai daya tarik pariwisata, dimana wisatawan berkunjung hanya untuk melihat potensi desa. Namun,sebaliknya trend tentang daya tarik pariwisata di Tanon salah satu desa di Semarang, Jawa Tengah berusaha untuk menawarkan yang lebih dengan membangun kekuatan desa sebagai "Desa Menari". Desa wisata ini menawarkan paket wisata yang mengajak wisatawan untuk merasakan kehidupan desa, berinteraksi dengan komunitas lokal, menemukan kebahagiaan dan menafsirkan kembali kehidupan. Tujuan penelitian ini adalah untuk mengetahui bagaimana pengalaman pribumi sebagai strategi mengembangkan identitas desa wisata berdasarkan teori komunikasi identitas (CTI). Penelitian ini menggunakan metode kualitatif dengan pendekatan studi kasus. Melalui observasi dan wawancara mendalam pada Kelompok Sadar Wisata, penelitian ini menemukan bahwa kelompok
\end{abstract}

*Corresponding author: bonifasiayr@gmail.com.

Copyright@ 2021 THE AUTHOR (S). This article is distributed under a Creative Commons Attribution-Share Alike 4.0 International license. Jurnal Kawistara is published by the Graduate School of Universitas Gadjah Mada. 
Sadar Wisata secara aktif memperkenalkan wisata berbasis pengalaman kearifan lokal melalui konservasi wisata Dusun Tanon, termasuk konservasi kesenian masyarakat, konservasi permainan tradisional masa lalu dan konservasi peternak. Pengalaman adat sebagai identitas desa dibangun sesuai dengan misinya, yaitu menyebarkan kerukunan, merajut inspirasi dan menuai memori. Identitas ini meliputi identitas pribadi, identitas relasional, dan identitas yang diberlakukan yang mengajak wisatawan untuk mengabadikan proses pemaknaan diri atau perjalanan kedalam dirinya sendiri sebagai pengalaman psikologis.

Kata Kunci: communication theory of identity (CTI); desa Menari; desa wisata; pemaknaan diri; pengalaman pribumi.

\section{INTRODUCTION}

Tourism is an important sector of economy development and contributes greatly to employment and Gross Domestic Product (GDP) especially in the developing countries.

Moreover, tourism is a rapidly growing industry with various economic benefits, such as to increase job creation and regional investment, it is also recognized as an industry that has a negative impact on the natural environment, society and culture (Dabphet, Scott, \& Ruhanen, 2012). As a result, there is growing agreement on the need to promote the concept of sustainable tourism development with the aim of minimizing environmental and socio-cultural impacts, while maximizing the economic benefits of tourist destinations (Lu \& Nepal, 2009).

Industrial tourism and tourist destination in international and national context has become competitive market. To be competitive, each destination strives to provide a quality experience and create the best value for its visitors while managing the impact of tourism on local communities and the environment. Improving service quality and creating the best value is closely related to the availability of good tourism products within tourist destinations. Tourism products are all the facilities needed by tourists so the provision of tourism products requires the support of many parties. Management of tourist destinations involves many parties in line with the characteristics of this sector. Tourism is an industry has unique characteristics. It involves multidimensional sectors (multi-sector, multi-actor, multi-regional and multi-aspect). In order to carry out the desired tourism development goals, this complexity of the multidimensional character of tourism makes this sector very dependent on integrated management.

This study explores and describes the concept of cultural tourism village in central Java Province deal with development the rural tourism identity. As an example, Desa Wisata Tanon has the concept of Cultural Tourism Village which is based on culture and creative economy. Dusun Tanon, located in the Central Java Province, Indonesia, was originally an underdeveloped village which then became an empowered village. In 2000, the people of Dusun Tanon had low income, the road infrastructure in this village were unpaved, and many children did not attend school. By 2012, this Dusun had turned into public area and become tourist destination, known as "outbound ndeso". Dusun Tanon even won Kampung Berseri Astra in the Environment Category of Satu Indonesia Award 2016 by Astra due to its community conservation which was related to the profession and development of tourism villages. In 2018, Dusun Tanon was visited by 1500 to 2000 visitors, earning IDR 100 million to IDR 260 million (Isnawati, 2018). This shows that tourism activities with the preservation of culture can be a source of income and provide benefits to the local communities (Buttler \& Hinch, 2007)

Dusun Tanon is more than just a place; it is a whole packaging of tourism in form of tourist attractions. Here, the tourists are invited to have an experience to live and feel the daily life in the village. This is the essence of tourism, which is associated with the growth of the economy and cultural experiences (Tung \& Ritchie, 2011; G Richards \& E Yeung, 2020)including attractions, events and tours, in Hong Kong. Four dimensions of experience (cognitive, conative, affective and novelty. Dusun Tanon introduces itself as "Desa Menari". This name does not only mean that there are 
dancing performances, but it is also integrated to the village's missions, namely spreading harmony, knitting inspiration, reaping memories, offering nostalgic and cultural tourism, as well as providing knowledge. Dusun Tanon attempts to develop its local strength as "Desa Menari" by offering tour packages that invite tourists to experience a life in the village. Desa Menari is a part of rural tourism shows how the tourists can live with local communities, interact with them, find happiness, and reinterpret their life. While traveling, tourists gain freedom, self-actualization, inner awareness, enlightenment, and/or more self-understanding (Sheldon, 2020). Thus, the purpose of traveling to Dusun Tanon for tourists is to divert their attention from the modern world, get a fresh mind, and restore their mentality or soul.

Desa Menari has identity formed from the interaction process of the local community through the local cultural tourism experiences which are then identified by tourists. Identity can reflect the reputation to public (Indrayani, Nurlita, \& Fitriani, 2020). This identity is formed through conservations carried out by rural tourism community of Dusun Tanon, consisting of the conservations of farmer, traditional games, and community arts. Conservation is one of the means of communication for Dusun Tanon in developing itself into a tourism village.

Regarding the object of this study, several previous studies have been conducted to discuss about the development of tourism (Adisti, 2018; Fuadi, Suharjo, Ratih, Utami, \& Sarbini, 2020) and the cultural acculturation (Susetyo \& Priyanto, 2018) in Dusun Tanon. The present study examined how indigenous experience acted as a strategy to develop the rural tourism identity by using the communication theory of identity (CTI).

This research is a descriptive research with qualitative approach inspecting the research questions and objectives in accordance with the research design. Qualitative research aims to explore and understand the meaning of, that by some individuals, was considered comes from the social and humanity problems (Creswell, 1994). By that approach the researcher has a greater chance to obtain a deeper and more complete data to answer research questions. For this descriptive study, the purpose was to establish the applicability how indigenous experience acted as a strategy to develop the rural tourism identity by using the communication theory of identity (CTI), utilizing a specifically selected study site. It sought to address the question of whether there was evidence of indigenous experience acted as a strategy to develop the rural tourism identity in the selected community setting. Both informal and semi-structured interviews (hereinafter, used interchangeably with interactions) were conducted with some individuals in the community. Interviews were preferred as a means of getting in-depth and contextual information on a variety of issues about rural tourism in the area. The choice of the interviewees was based on the principles of optional sampling in which the researchers choose the informants to be interviewed. The optional sampling is often utilized in the cases where expert information is needed.

The data used for this study was obtained through literature review, field observation, and in-depth interview with several community leaders from rural tourism community of Desa Menari as the respondents. Participants or respondents included one accommodation staff, one senior members of the Village Trust Committee, one elderly community members and one local tour guides responsible for many different sites in the area. The interviews took place on same date and at different times, primarily determined by the informants' convenience. With the members of the trust, and accommodation staff, the interactions were semi-formal in that the researcher made prior appointments and discussed with them for about 1 till 2 hours.

The interactions themselves were partly informal but followed a prepared interview guide and centred around issues of rural tourism in the area with guiding questions from the researcher.Interviews were conducted in Dusun Tanon, Kabupaten Semarang, Central Java Province, Indonesia . All 
respondents were fluent in Bahasa and so is the researchers who handled the interviews. Field notes were used to record the information from interviews and observations during the field visit. Analysis was performed using thematic approach.

Thestudywasconductedinandaroundplace called Dusun Tanon. Dusun Tanon is one of the dusun(subvillage) located in Ngrawan Village, GetasanDistrict,SemarangRegency.Itislocated atthefootofMountTelomoyo, witharuralatmosphere that is still beautiful, cooland farfrom the hustleand bustleofmodernlife.DusunTanonitself is not too far from the city. The distance between Dusun Tanon and Salatiga City itself is $11.7 \mathrm{~km}$, to Solo $50 \mathrm{~km}$, to Yogyakarta 76, $28 \mathrm{~km}$, and to Magelang $33.3 \mathrm{~km}$. This makes access to Dusun Tanon is easy and affordable.

With the location of Dusun Tanon at the foot of Mount Telomoyo, it certainly produces a lot of vegetables, because most of the residents work as farmers. Dusun Tanon has its own charm for tourists because of its different tourism attraction from others, namely interesting art and cultural performances. The number of residents in Dusun Tanon in 2020 is known to be 160 people, including 81 women and 79 men. It should be noted that the residents of Dusun Tanon are all Muslims.

In the past, Tanon was just a "unknown dusun", the same as the other dusun, in fact there was nothing special at all. The people of Dusun Tanon themselves also still maintain the procedures from their ancestral traditions. Dusun Tanon is a community whose social community is easily mobilized by art media. This is an effective way to move the community towards the next learning. On the other hand, the lives of the people who are mostly farmers become an inseparable part to support the pillars of society. With the idea from young people on how to manage the potential of the existing nature, it has become a market commodity that is worthy of being traded.

This exploration led to the management of cow's milk produced from community cultivation into milk soap. The potential of agriculture combined with livestock in the future is an exploration to be developed to advance the community's economy. So that they, namely the people of Dusun Tanon, are expected to be maintained as people who are engaged in the arts and are materially productive.

\section{DISCUSSION \\ Conservation as a Form of Tourism Village Development}

Dusun Tanon is located on the slopes of the charming Mount Telomoyo, and most of the people's livelihoods are farmers. Most of those who migrated to other areas only worked as laborers. This small village is inspired for young villagers who get bachelor degree in psychology have a desire to develop the village. The respondents of this study, who are the community leaders, initiated "Outbound Ndeso" as a way to attract tourists to experience a life in the village. There are six tour packages to choose from and enjoy. They have three main themes, namely the conservation of farmers, conservation of traditional games, and conservation of community arts. These conservations are based on rural tourism, which main point is to increase the level of agriculture in a sustainable manner (Ohe, 2020). Every tourist visit to Desa Menari involves 98 percent of the local village residents. This sustainability is defined as maintaining, preserving, and sharing the long-term cultural interactions, values and equal rights, lifestyle, and the quality of life of the local communities in the rural tourism destinations (Fong, et al., 2017, p.149; Sharma, Pulido-Fernández, \& Hassan, 2020). Therefore, Dusun Tanon can be seen as a tourism village which combines tourist attractions, accommodation, and other supporting facilities presented in a structure of community life integrated with the prevailing procedures and traditions through conservation.

Conservation is carried out as an effort for sustainable development which leads to the formation of the sphere of mind (noosphere), a concept developed and popularized by V.I. Vernadsky when spiritual values and knowledge are in harmony with the nature that they bring out the wealth of individ- 
ual thoughts (Nasibulina, 2015). This individual thought is called mindfulness, which first step is the awareness of the object and the second step is deep observation at the object to shed light on it (Wang, Chen, Shi, \& Shi, 2021). Therefore, conservation as sustainable development must be embodied and understood as a moral and historical goal, and it needs to move from material to spiritual civilization. Based on the respondent's statement, Desa Wisata not only introduces and maintains the culture of the village but also builds interactions with the nature as for a measure of nature conservation.

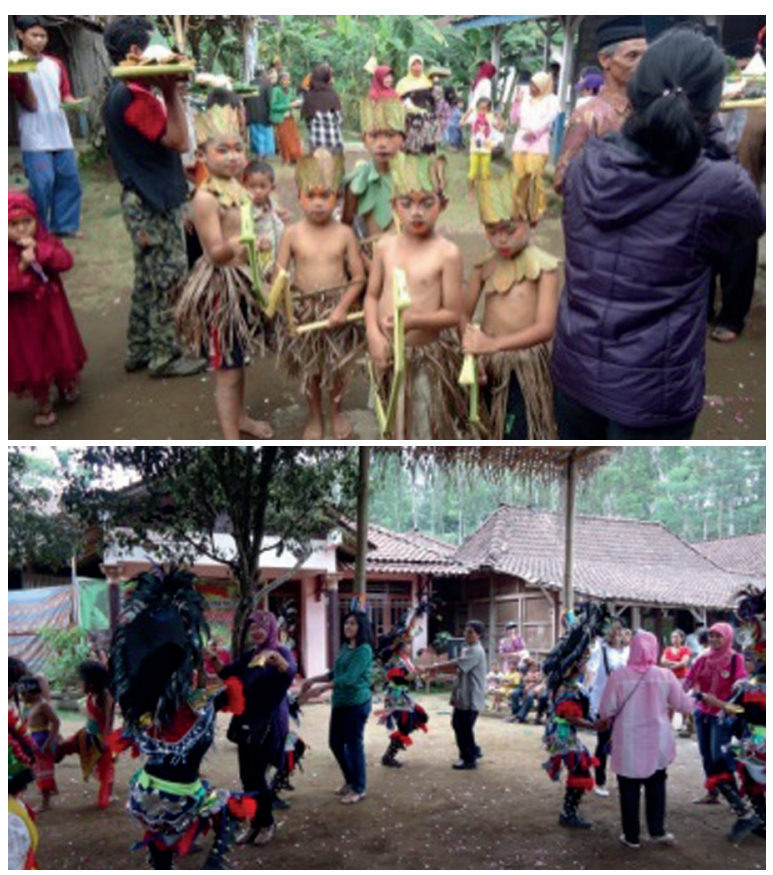

Figure 1

Conservation of Community Arts

Source: Pokdarwis Dusun Tanon, 2020.

The conservation of community arts can be seen in Figure 1; tourists are invited to dance together with the locals to get to know their culture. In general, the villagers have been preserving folk dances from generation to generation. Children have been taught to dance since they were young. Among the dances mastered by the villagers are Tari Warok, Tari Topeng Ayu, Kuda Debog, Geculan Bocah, Kuda Lumping, and Tari Eko Prawiro. There is also Ngames Bocah, a dance performed by the children. Tourists are encouraged to be involved in their dancing activities.

Cultural performances are presented not only for viewing purposes, but also for direct interaction between the tourists and the residents. This is what is called the visitor attraction, where tourists experience the local arts of Dusun Tanon in the context of tourism. According to Richards (2018), onsite tourism experience is the most influential antecedent of revisiting intentions.

The second conservation done in Dusun Tanon is the conservation of traditional games as depicted in Figure 2. In the conservation of past traditions, tourists get to try playing various traditional games, such as Gobag Sodor, Layangan, Tali Bambu, and many others. Here, tourists are invited to feel the sensation of the local wisdom on how traditional Javanese games still exist.

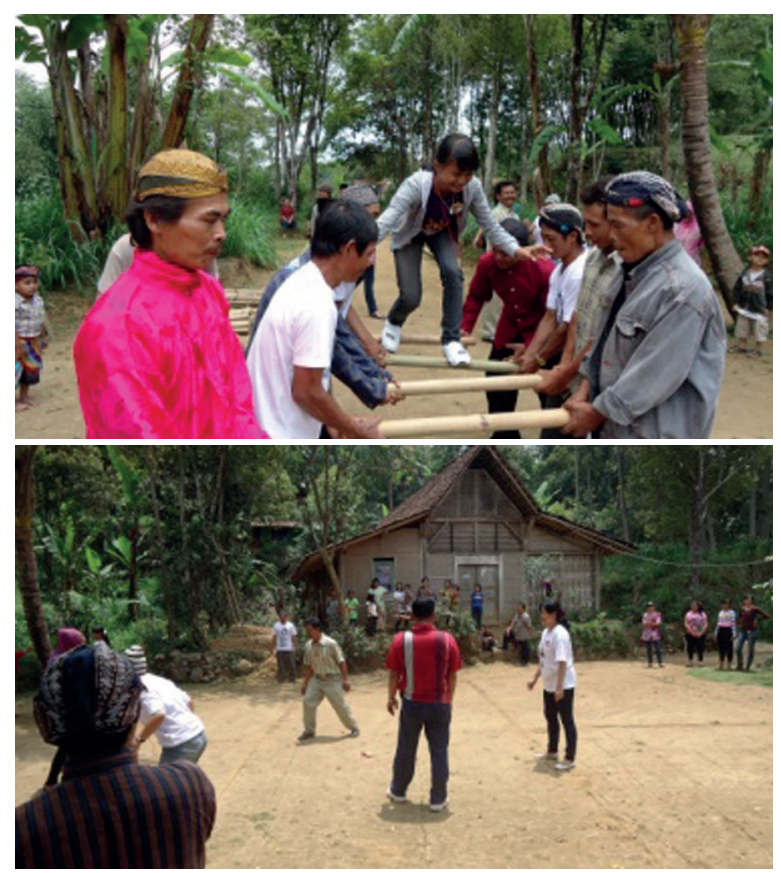

Figure 2

Conservation of Local Traditions Source: Pokdarwis Dusun Tanon, 2020.

The conservation of traditional games is a way to reminisce the past and a means of education. Reaping memories is one of the tourism goals of Desa Menari which brings to life the charm of the countryside. Traditional 
games are reminiscent of past experiences before the development of technology.

The third conservation in Dusun Tanon is the conservation of farmers as presented in Figure 3, where tourists are welcomed to milk the cattle. The sources of income for the residents of Desa Menari are from farming and breed cattle.

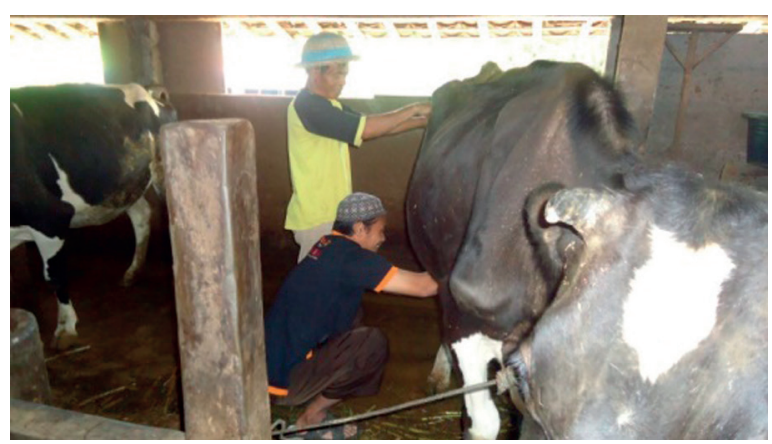

Figure 3

Conservation of Breeders

Source: Pokdarwis Dusun Tanon, 2020.

The conservations carried out by rural tourism community of Desa Menari in Dusun Tanon are the preservation of the local culture by means of tourism experiences. The tourists are then introduced to the processed agricultural products of Desa Menari. The creative economy products of the community of Desa Menari were presented to the tourists during their visits. The people of Desa Menari, which is based on agriculture and animal husbandry, produce processed agricultural products such as tofu, chips, fennel sticks, corn sticks, beet powder, turmeric powder, and milk soap (AS, 2017). These processed products are well-packaged and standardized so that they have a competitive selling value.

The potentials of the community of Desa Menari in building up its local strength to strive for its independence can be seen in tourist visits. Local economic growth supports the development of tourism villages and regional economic development increases competitiveness in the economic growth (Rabe, Osman, \& Bachok, 2014).

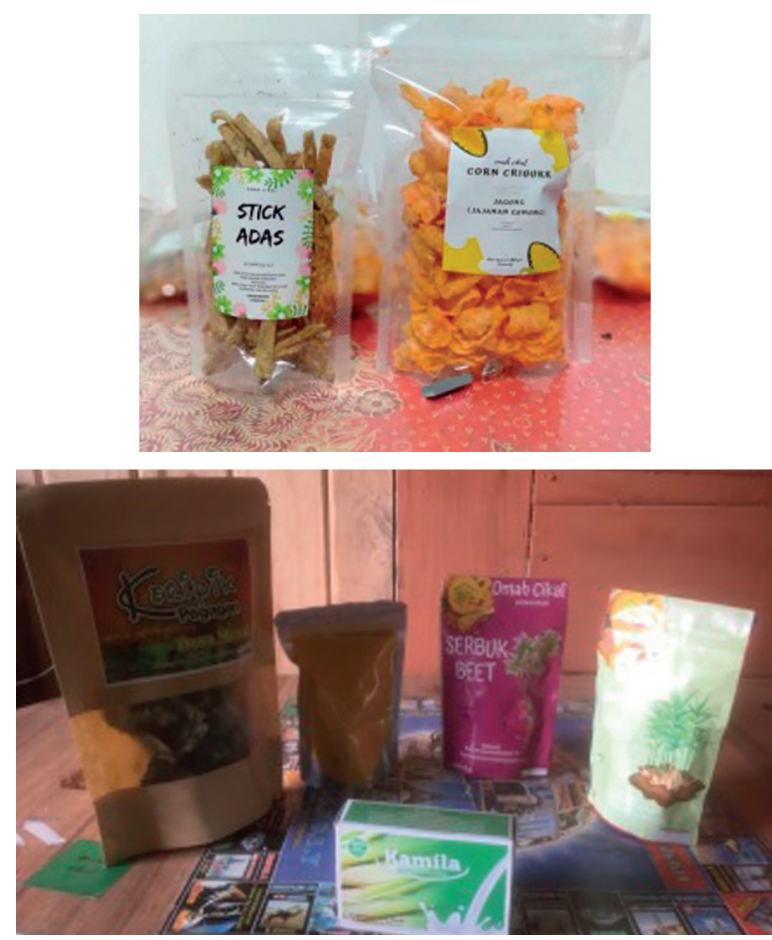

Figure 4

Products of Creative Economy

Source: Personal Documentation, 2020

The community independently makes processed traditional food products and handicrafts which are then marketed in the public market. Tourist visits are the gateway to introduce the potential of the village through direct interaction. Pasar Rakyat is a meeting space between the people of Desa Menari as the sellers of creative economy products and the tourists as their consumers. Traditional markets with the concept of bargaining give a distinct impression for tourists coming from outside Desa Menari. Here, tourists can directly enjoy various menu of traditional food, such as nasi jagung, tempe goreng, bobor adas, and bobor daun labu siam. In addition, there are also handicrafts and processed products that they can buy and take home as souvenirs. Richards, et al. (2020) including attractions, events and tours, in Hong Kong. Four dimensions of experience (cognitive, conative, affective and novelty argued that these experiences, accompanied by the availability of local goods and/or services from the destination, can attract tourists. 


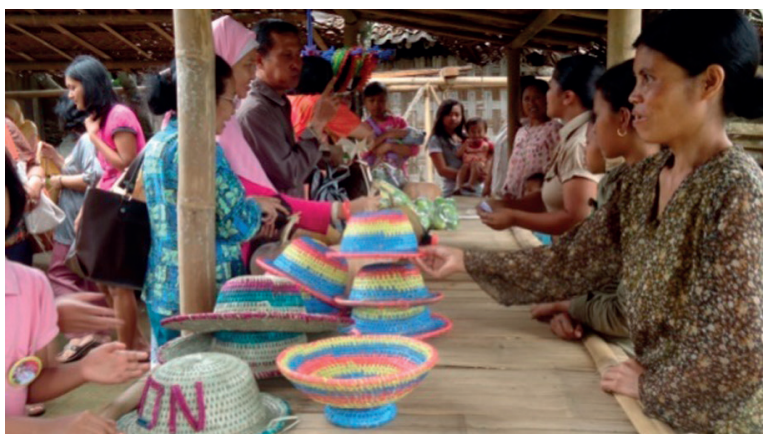

Figure 5

Pasar Rakyat (lit. Public Market)

Source: Pokdarwis Dusun Tanon, 2020.

Conservation sequences elicit performative experiences of authenticity and offer a deep understanding of the relationship between memory, habitus, and embodied practice. This idea of "performative authenticity" describes a transitional and transformative authentication process. The production of such performative authenticity also concerns with increasing the amount of emotional labor of those involved with the inherited resource (Van Dijk \& Kirk, 2007; Richards, 2018).

\section{Indigenous Experience Tourism as Village Identity}

Indigenous experience was built according to its missions, namely spreading harmony, knitting inspiration, and reaping memory. This is in line with the conceptualization of sustainability which includes the idea of living in harmony with the nature and in balance with the Mother Earth, with a deep spiritual dimension. (Hill, et al., 2020). Through "outbound ndeso", tourists are invited to engage in activities that have the meanings of fostering empathy for others, appreciating the process on everything, understanding that the basic professional actors are the keepers of the chain of life, being grateful in life, and learning from nature.

One example for this is when the tourists joined a tour and studied about the agriculture. In the tour, they followed and took part in the process of farming, where at first they complained about the high price of basic necessities. Then, they were invited to witness the whole process. At one moment, they were offered to stay at a resident's house. Then, they participated in the activities done by their host, who is the owner of the house they were staying. One of the activities was planting chilies, which at that time was expensive; a kilo of chilies was sold for IDR 50 thousand. The tourists were invited to harvest the chilies with the host. They walked 30 minutes to get to the fields. When going alone, it normally takes around 10-15 minutes for the host to reach the field. However, as he went with his guests, he took his time to accompany the tourists and walk slower. Arriving at the field, they harvested chilies from 8 am to $1 \mathrm{pm}$. In five hours, they got 1 basket of chilies and sold them to the middlemen for only IDR 30 thousand. After experiencing that process, the tourists cried at night. They had been more grateful then before, when they complained about the price of basic commodities. They gained this feeling after witnessing the life of villagers who farm to make ends meet, no matter how far the road they have to take, how long the time they have to spend to harvest, and how little money they earn from all the hard works. This is when the tourists finally found the insight that there are countless ways to be grateful. By experiencing the life of the community, they can find the meaning in life. This is what indigenous experience tourism is. As Burnett and Haperin underlines that Indigenous experience tourism is defined as an active and sustainable potency associated with the restoration and preservation of the traditions, relationships, and culture of indigenous people, so that positive and demonstrative changes are possible (Burnett, Sanders, Halperin, \& Halperin, 2020). Indigenous tourism is defined as an activity with the direct involvement of indigenous people in interacting with the tourists to display local cultural attractions (Butler \& Hinch, 2007; Ruhanen, Whitford \& McLennan, 2015).

The interaction between villagers and tourists creates mutual benefits. For the tourists, they can get to know the local wisdom. As for the local people, they believe that outsiders can learn from them and their villages. The process of indigenous experience is what forms the 
identity of Dusun Tanon as Desa Menari. When the tourists travel to Dusun Tanon and join a tour there, they are experiencing indigenous tourism. Therefore, the strategy is to develop the rural tourism based on the communication theory of identity (CTI), in which identities and identification are key processes through which people and groups orient themselves to each other and to the world around them. According to Xue, Kerstetter, \& Hunt (2017), identity can be managed, represented, and rebuilt.

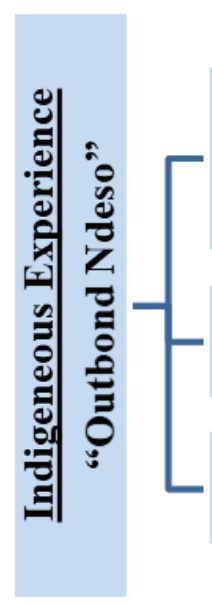

\section{Personal Identity}

(Javanese culture: language, traditional game, traditional game, rural economic system)

\section{Relational Identity}

(psychological oasis: sensation of being grateful)

\section{Enacted Identity}

(social relations: sense of place from cultural production)

Figure 6

Indigenous Experience Tourism as a Strategy to Develop Rural Tourism Identity

Source: Developed by the researchers, 2021.

There are three main aspects to note in the communication theory of identity initiated by Michael Hecht and his colleagues, namely personal identity, relational identity, and enacted identity (Littlejohn \& Foss, 2009). The residents of Dusun Tanon identify themselves as a group of villagers who preserve Javanese culture through artistic activities, professions, and daily life. Therefore, the residents of Dusun Tanon as the indigenous people have a hereditary active participation in managing the tourism village. Personal identity is seen from the residents of Dusun Tanon as the indigenous people of certain area who are maintaining their own customs and traditions (Hill, et al., 2020).

Based on the United Nations Development Programme 2004, indigenous people own certain characteristics, including: (1) self-identification as a part of a preserved culture; (2) language identity, traditions, as well as social, political, and economic systems which are different from those of the dominant society; and (3) traditional economic management and strong ancestral ties (Ryan \& Aicken, 2005). As mentioned previously, the people of Dusun Tanon identify themselves as a part of the Javanese traditional cultural group, and they show a strong desire to preserve this cultural identity. Their different linguistic identities from the dominant society are shown by the use of Javanese as their everyday language and introduced to the tourists during interactions. Another characteristic of the residents of Dusun Tanon as the indigenous people is seen from the tradition of preserving traditional dance and games and protect them against modernization as in digital-based dances and games. Furthermore, the economic system in Dusun Tanon is more oriented towards agricultural products and has strong ties to their ancestors as well as the natural resources in this small village, which is located on the slope of Mount Telomoyo. (Xue, et al., 2017) stated that the formation of identity is based on the representations of local culture, traditions, and heritage. This is a description of how the residents of Dusun Tanon see themselves as a personal identity.

The second aspect in CTI is relational identity, namely how the others see us. The systemic approach makes indigenous experience an identity without changing anything for tourists to visit. The results showed that tourists with a modern cultural background look for trips to villages to fulfill their psychological need. The experience to find happiness in simplicity and the sensation of being grateful have formed the identity of the people of Dusun Tanon offered in their indigenous experience tourism. The longing for the village atmosphere that prioritizes harmonious humanitarian relations makes tourists always want to return to Tanon Dusun as "tamu balen", a term used for people who visit Dusun Tanon repeatedly. This is what is meant by a relational identity. 
The third aspect in the communication theory of identity is the enacted identity, namely how we express ourselves. In this case, the place-bound identity is the enacted identity. The rural natural atmosphere in Dusun Tanon is another identity that attracts tourists to join Outbound Ndeso. The countryside becomes a space for recreation and tourism activities (Fløysand \& Jakobsen, 2007; Panelli, 2006; Xue, et al., 2017). This can also be called a place-bound identity which integrates the society, culture, and nature. According to Kotler, Kartajaya, \& Iwan (2016), culture covers all human creations such as arts (dance, music, and theater), crafts, festivals, and many others. Nature is seen as all kinds of activities related to the nature. Meanwhile, adventure combines culture and nature added to the challenge.

In tourism activities which include the society, culture, and nature, the identity is seen not only from the village as the infrastructure but also from its social elements. The symbol of place-bound identity is a mediation regulated at the level of social interaction itself, which is used as a tool to facilitate everyday life by organizing and directing the symbols of action. Furthermore, everything related to the image of a place occurs in group identity. To understand place-bound identity as a "sense of place", how a space or place is formed needs to be determined. Thus, identity is the result of the construction of social relations, meetings, and ties together at a particular locus (Kalandides, 2011; Fitri \& Triyadi, 2015). The construction of social relations is built from the tourist attractions and the tourist activities in which the tourists then recognize, experience, and immerse themselves in the cultural "production" as the meaning and reflection of life after learning it from indigenous people (Ryan \& Aicken, 2005).

In order to always pass on its identity from generation to generation, rural tourism community of Dusun Tanon educates the public about its local traditions. This education is based on classical educational traditions, such as fundamental character, depth, interdisciplinarity, continuity, and humanism. Children are taught to dance, play gamelan, farm, breed, and the other local wisdoms. Nonetheless, a systemic approach to the interaction of the society, culture, and nature must be at the heart of this process (Nasibulina, 2015). Identity is formed from the residents of Dusun Tanon who live the values of a village life then teach the tourists about it so that they can finally understand themselves better by reflecting on their experiences after traveling.

\section{CONCLUSION}

Dusun Tanon is known-as Desa Menari not a mere tourism object with profitable tourism activities; it possesses a deeper meaning of local wisdom, namely the indigenous tourism experience. The identity of indigenous tourism experience is constructed from personal identity, relational identity, and enacted identity. The residents of Dusun Tanon identified themselves as indigenous people through the conservations of breeder, traditional games, and community arts as the place-bound identity. The relational identity is developed with the presence of "tamubalen", a term for tourists who visit Dusun Tanon repeatedly. This sustainable identity invites tourists to capture the process of self meaning or a journey into oneself. Indigenous experience tourism reflects the identity of Dusun Tanon as a process of harmonious life and a memorable place of inspiration.

\section{BIBLIOGRAPHY}

Adisti, S. W. (2018). Pengembangan Desa Wisata Menari Tanon Kabupaten Semarang. Universitas Sebelas Maret Surakarta.

AS, A. (2017). Astra Kembangkan Desa Wisata Tanon. Retrieved April 12, 2020, from swa.co.id website: https:/ / swa.co.id/swa/csr-corner/ astra-kembangkan-desa-wisatatanon 
Burnett, K., Sanders, C., Halperin, D., \& Halperin, S. (2020). Indigenous Peoples, Settler Colonialism, and Access to Health Care in Rural and Northern Ontario. Health and Place, 66(September). https://doi.org/10.1016/j. healthplace.2020.102445

Buttler, R., \& Hinch, T. (2007). Tourism and Indigenous Peoples: Issues and Implications. UK: Elsevier Ltd.

Creswell, J. W. (1994). Research design: Qualitative and Quantitative Approaches. California: Sage Publications.

Dabphet, S., Scott, N., \& Ruhanen, L. (2012). Applying Diffusion Theory to Destination Stakeholder Understanding of Sustainable Tourism Development: a Case from Thailand. Journal of Sustainable Tourism, First 2012, 1-18.

Fitri, M., \& Triyadi, S. (2015). Community Cultures in Creating the PlaceBound Identity in Musi Riparian, Palembang. Procedia - Social and Behavioral Sciences, 184(August 2014), 394-400. https:// doi.org/10.1016/j. sbspro.2015.05.108

Fuadi, D., Suharjo, S., Ratih, K., Utami, R. D., \& Sarbini, D. (2020). Pengembangan Dewi Menari sebagai Desa Wisata Tanon Lereng Gunung Telomoyo di Kecamatan Getasan, Kabupaten Semarang. Buletin KKN Pendidikan, 2(1), 28-36. https://doi. org/10.23917/bkkndik.v2i1.11268

Hill, R., Adem, Ç., Alangui, W. V., Molnár, Z., Aumeeruddy-Thomas, Y., Bridgewater, P., ... Xue, D. (2020). Working with Indigenous, Local and Scientific Knowledge in Assessments of Nature and Nature's Linkages with People. Current Opinion in Environmental Sustainability, 43(January), 8-20. https:// doi.org/10.1016/j.cosust.2019.12.006

Indrayani, H., Nurlita, R., \& Fitriani, J. D. (2020). Manajemen Strategis Public
Relations: Teori dan Praktik Corporate dan Government Public Relations (A. Wikan, Ed.). Jakarta: PR Indonesia.

Isnawati. (2018). Pemberdayaan Ekonomi dalam Harmoni Alam dan Tradisi di Desa Menari. Retrieved April11,2020, from suaramerdeka.com website: https://www.suaramerdeka.com/ news/baca/156137/pemberdayaanekonomi-dalam-harmoni-alam-dantradisi-di-desa-menari

Kotler, P., Kartajaya, H., \& Iwan, S. (2016). Marketing 4.0: Bergerak dari Tradisional ke Digital. Jakarta: PT Gramedia Pustaka Utama.

Littlejohn, S. W., \& Foss, K. A. (2009). Encyclopedia of Communication Theory. USA: Sage Publications, Inc.

Lu, J., \& Nepal, S. K. (2009). Sustainable Tourism Research: an Analysis of Papers Published in the Journal of Sustainable Tourism. Journal of Sustainable Tourism, 17(1), 5-16.

Nasibulina, A. (2015). Education for Sustainable Development and Environmental Ethics. Procedia - Social and Behavioral Sciences, 214(June), 10771082. https://doi.org/10.1016/j.sbspro.2015.11.708

Ohe, Y. (2020). Community-based Rural Tourism and Entrepreneurship: A Microeconomic Approach. In Springer. $\quad$ https://doi.org/10.1007/978981-15-0383-2

Rabe, N. S., Osman, M. M., \& Bachok, S. (2014). Economics of Local People: Iskandar, Malaysia. Procedia - Social and Behavioral Sciences, 153, 463478. https://doi.org/10.1016/j. sbspro.2014.10.080

Richards, G. (2018). Cultural Tourism: A Review of Recent Research and Trends. Journal of Hospitality and Tourism Management, 36, 12-21. https://doi. org/10.1016/j.jhtm.2018.03.005 
Richards, G., King, B., \& Yeung, E. (2020). Experiencing Culture in Attractions, Events and Tour Settings. Tourism Management, 79. https://doi. org/10.1016/j.tourman.2020.104104

Ruhanen, L., Whitford, M., \& McLennan, C. lee. (2015). Indigenous Tourism in Australia: Time for a Reality Check. Tourism Management, 48, 73-83. https:// doi.org/10.1016/j.tourman.2014.10.017

Ryan, C., \& Aicken, M. (2005). Indigenous Tourlsm: The Commodification and Management of Culture. In Elsevier Ltd. https://doi. org/10.4324/9780080914008

Sharma, A., Pulido-Fernández, J. I., \& Hassan, A. (2020). Sustainable Destination Branding and Marketing: Strategies for Tourism Development. Retrieved from https://books.google.com/books?h $1=$ en\&lr=\&id=RonHDwAAQBAJ\&o $\mathrm{i}=$ fnd\&pg $=$ PR $3 \& d q=$ marketing + the +school\&ots=nb64sqH6VL\&sig=IsG UT1iH8Ul3YrpR72ucPPmermM
Sheldon, P. J. (2020). Designing Tourism Experiences for Inner Transformation. Annals of Tourism Research, 83(January), 1-12. https://doi. org/10.1016/j.annals.2020.102935

Susetyo, D. B., \& Priyanto, P. H. (2018). Strategi Akulturasi dan Pengembangan Desa Menari Dusun Tanon - Kab. Semarang. Universitas Soegijapranata Semarang.

Wang, Y. C., Chen, P. J., Shi, H., \& Shi, W. (2021). Travel for Mindfulness through Zen retreat Experience: A Case Study at Donghua Zen Temple. Tourism Management, 83. https:/ / doi. org/10.1016/j.tourman.2020.104211

Xue, L., Kerstetter, D., \& Hunt, C. (2017). Tourism Development and Changing Rural Identity in China. Annals of Tourism Research, 66, 170182. https://doi.org/10.1016/j. annals.2017.07.016 